\title{
GC-MS Analysis of Essential Oil from Long Pepper Growing in Tepi, South-west Ethiopia
}

\author{
Bizuneh Adinew
}

Department of Chemistry, Mizan-Tepi University, Tepi campus, P.O. Box 121, Mizan-Tepi, Ethiopia

\begin{tabular}{|c|c|}
\hline Abstract & Article Information \\
\hline $\begin{array}{l}\text { The objectives of the study were to extract and identify essential oils present in Long } \\
\text { pepper by using gas chromatography-mass spectrometry (GC-MS). The essential oil } \\
\text { of Long pepper growing in Tepi, Ethiopia, was obtained by hydro distillation and gas } \\
\text { chromatography-mass spectrometry was used to identify the component. Five } \\
\text { components were identified and eugenol was the major constituent }(98.979 \%) \text { while } \\
\text { trans-caryophyllene, }(0.643 \%) \text {, Preg-4-ene-3-one }(0.149 \%) \text {, Phenol, } 2 \text {-methoxy-4-(2- } \\
\text { propenyl)-, acetate }(0.145 \%) \text {, and } 1,3,6-\text {-Octatriene, 3, 7-dimethyl }(0.084 \%) \text { were } \\
\text { minor constituents. Eugenol comprises } 98.979 \% \text { of the essential oil extracted from }\end{array}$ & $\begin{array}{l}\text { Article History: } \\
\text { Received : 03-01-2014 } \\
\text { Revised : 12-03-2014 } \\
\text { Accepted : } 19-03-2014 \\
\text { Keywords: } \\
\text { Long pepper } \\
\text { Hydro distillation } \\
\text { Extraction }\end{array}$ \\
\hline $\begin{array}{l}\text { Long pepper, and is the compound most responsible for the Long pepper s' aroma and } \\
\text { therapeutic effect. } \\
\text { Copyright@2014 STAR Journal. All Rights Reserved. }\end{array}$ & $\begin{array}{l}\text { *Corresponding Author: } \\
\text { Bizuneh Adinew } \\
\text { E-mail: buzeadinew@gmail.com }\end{array}$ \\
\hline
\end{tabular}

\section{INTRODUCTION}

Essential oils (also called volatile or ethereal oils); are aromatic oily liquids obtained from plant material (flowers, buds, seeds, leaves, twigs, bark, herbs, wood, fruits and roots) (Guenther, 1948). The essence or aromas of plants are due to volatile or essential oils, many of which have been valued since antiquity for their characteristic odors. The essential oils have characteristic fragrances and tastes are mixtures of known and unknown compounds. They may contain hydrocarbons, terpene alcohols, aldehydes, ketones, phenols and esters (Denston, 1939). An estimated 3000 essential oils are known, of which about 300 commercially important are destined chiefly for the flavors and fragrances market (Van de Braak and Leijten, 1999). It has long been recognized that some essential oils have antimicrobial properties (Guenther, 1948; Boyle, 1955) and these have been reviewed in the past (Shelef, 1983; Nychas, 1995) as have the antimicrobial properties of spices (Shelef, 1983) but the relatively recent enhancement of interest in 'green' consumerism has lead to a renewal of scientific interest in these substances (Nychas, 1995; Tuley de Silva, 1996). Besides antibacterial properties (Deans and Ritchie, 1987; Carson et al., 1995a; Mourey and Canillac, 2002), essential oils or their components have been shown to exhibit antiviral (Bishop, 1995), antimycotic (Azzouz and Bullerman, 1982; Akgul and Kivanc, 1988; Jayashree and Subramanyam, 1999; Mari et al., 2003), antitoxigenic (Akgul et al., 1991; Ultee and Smid, 2001; Juglal et al., 2002), antiparasitic (Pandey et al., 2000; Pessoa et al., 2002), and insecticidal (Konstantopoulou et al.,1992; Karpouhtsis et al., 1998) properties. These characteristics are possibly related to the function of these compounds in plants (Guenther, 1948; Mahmoud and Croteau, 2002).
Due to their antimicrobial, insecticidal, antifungal, and antibacterial activities, essential oils have been intensely screened and applied in the fields of pharmacology, medical and clinical micro-biology, phytopathology and food preservation (Daferera et al., 2000).

Techniques commonly employed for extracting essential oils include hydro distillation (ASTA, 1968), steam distillation (Chialva et al., 1982), solvent extraction (Burbott and Loomis, 1967), supercritical fluid extraction. Hydro distillation or steam distillation is the most widely utilized physical method for isolating essential oils from the botanical material (Whish, 1996 and Masango, 2004). Although steam distillation is much popular for the isolation of essential oils on commercial scale and $93 \%$ of the oils are produced by this process, but it is not a preferred method in research laboratories (Masango, 2004). This is probably due to unavailability of steam generators and suitable distillation vessels. Most studies which focus on the essential oil of herbs have made use of hydro distillation in Clevenger-type apparatus (Kulisic et al., 2004; Sokovic and Griensven, 2006; Hussain et al., 2008).

Several authors have compared the composition of essential oil obtained by hydro/steam distillation and the product obtained by super critical fluid extraction. They found that hydro/steam-distilled oil contained higher percentages of terpene hydrocarbons. In contrast, the super critical extracted oil contained a higher percentage of oxygened compounds (Reverchon, 1997; Donelian et al., 2009). Khajeh et al., (2004) reported variation in the chemical composition of Carum copticum essential oil isolated by hydro distillation and supercritical fluid extraction methods. Silva et al., (2004) reported that 


\section{Bizuneh Adinew}

essential oils from leaves of Ocimum gratissimum, Ocimum micranthum and Ocimum selloi obtained by steam distillation, microwave oven distillation and supercritical extraction with $\mathrm{CO}_{2}$ showed different composition by GC-MS analysis.

Gas chromatography-mass spectrometry (GC-MS) is the most popular method for the determination of essential oil composition. Components existing in the essential oil can be identified by comparison of their relative retention time or indices and their mass spectra (MS). Identification of individual components of essential oils, however, is not always possible using MS data alone. Often different spectra are reported in a library for a single compound, with different common names, or systematic name, corresponding to an individual component sometimes apparent (Sheille et al., 2002). The spectral similarity of a great number of essential oil components causes difficulty in obtaining positive identification of individual components; mass spectra for sesquiterpenes are often identical or nearly identical (Konig et al., 1999). Some authors have also evaluated different techniques for essential oil analysis, like the more comprehensive two-dimensional gas chromatography (Dimandja et al., 2000; Sheille et al., 2002). However, GC-MS analysis is still the most widely used method for routine analysis of essential oils, and care must be taken to optimize the chromatographic conditions in order to obtain the most accurate results. The present study aims to investigate the chemical composition of Long pepper essential oil by GC-MS analysis.

\section{METHODS AND MATERIALS}

\section{Plant Material}

The plant material (Long pepper) was collected from local market, Tepi, in February 2013. Plant material was identified by Ethiopian Institute of Agricultural Research Tepi national Spice Research Center and transported to chemistry laboratory for essential oil extraction.

\section{Hydro Distillation (Extraction of essential oil)}

$300 \mathrm{gm}$ of cleaned and dried plant material was powdered using metal mortar and pestle and placed in a round bottom flask fitted with condenser hydro distilled for $3 \mathrm{hrs}$ at atmospheric pressure and constant temperature. The strongly aromatic oil was separated from the water layer using diethyl ether and the solvent was removed by boiling.

\section{Fourier Transform Infrared Spectroscopy (FT-IR)}

The FT-IR spectrum of the essential oil was obtained using prinks Elmer spectrum65 FT-IR spectrometer in Addis Ababa University and functional groups were determined with the help of correlation charts. The IR spectra were reported in \% transmittance. The wave number region for the analysis was $4000-400 \mathrm{~cm}^{-1}$ (in the mid-infrared range).

\section{GC-MS Analysis}

The component identification was achieved by the GCMS analysis using HP 5890 series GC equipped with mass selective detector (MSD), HP 5972 series (German) in Addis Ababa University. Helium was used as carrier gas at a constant flow of $1 \mathrm{ml} / \mathrm{min}$ and an injection volume of $1 \mu \mathrm{l}$ was employed, injector temperature $250^{\circ} \mathrm{C}$; Ionsource temperature $280^{\circ} \mathrm{C}$. The oven temperature was programmed from $50^{\circ} \mathrm{C}$ (isothermal for $4 \mathrm{~min}$.), with an increase of $3^{\circ} \mathrm{C} / \mathrm{min}$, to $280^{\circ} \mathrm{C}$ and held for $10 \mathrm{~min}$.
Sci. Technol. Arts Res. J., Jan-March 2014, 3(1): 31-38

isothermal at $280^{\circ} \mathrm{C}$. Total $\mathrm{GC}$ running time was 90.67 $\min$.

\section{Identification of Components}

The components of essential oil was identified on the basis of comparison of their retention time and mass spectra with published data (Massda, 1976; Adams, 2001) and computer matching with WILEY 275 and National Institute of Standards and Technology (NIST3.0) libraries provided with computer controlling the GC-MS system, in Addis Ababa University, Ethiopia. The spectrum of the unknown component was compared with the spectrum of the known components stored in the library. The Name, Molecular weight and Structure of the components of the test materials were ascertained.

\section{RESULTS AND DISCUSSION}

The retention times and chemical composition of phytocomponents present in Long pepper essential oil are presented in Table 1.

\section{Determination of the Functional Groups using FT-IR}

The functional groups present in the essential oil were determined by comparing the vibration frequencies in wave numbers of the sample spectrograph obtained from an FT-IR spectrophotometer with those of an IR correlation chart. In the FT-IR spectrum of Long pepper essential oil the absorption band or frequency from 3500 $\mathrm{cm}^{-1}-3200 \mathrm{~cm}^{-1}$ ( strong and broad), showed the presence of $\mathrm{O}-\mathrm{H}$ stretch, $\mathrm{H}$-bonded for alcohol and phenol and $3000 \mathrm{~cm}^{-1}-2850 \mathrm{~cm}^{-1}$ (medium) indicate $\mathrm{C}-\mathrm{H}$ stretch for alkane. The absorbance band from $1600 \mathrm{~cm}^{-1}-1580 \mathrm{~cm}^{-1}$ (medium) revealed the presence of $\mathrm{C}-\mathrm{C}$ stretch (in-ring) for aromatics. A strong absorption band between $1550 \mathrm{~cm}^{-}$ ${ }^{1}-1475 \mathrm{~cm}^{-1}$ indicated the presence of $\mathrm{N}-\mathrm{O}$ asymmetric stretch for nitro compounds. A medium-weak band between $1680-1600 \mathrm{~cm}^{-1}$ showed the presence of alkenes $\mathrm{C}=\mathrm{C}$ stretch. The presence of strong band between $1320 \mathrm{~cm}^{-1}-1000 \mathrm{~cm}^{-1}$ indicates the presence of C-O stretch for alcohols functional group (Figure 1).

\section{GC-MS Chromatogram}

A total of five components, with different retention times, were eluted from the GC column as indicated by the chromatogram (Figure 2) and were further analyzed with an electron impact MS voyager detector. Identification of constituents was done on the basis of their retention time and mass spectra library search. The mass spectrographs of the identified constituents are given in figure 3 to 7 . The relative amount of individual components was calculated based on GC peak areas.

Comparison of the GC-MS spectrograph obtained with the instruments data bank together with computer matching with WILEY 275 and National Institute of Standards and Technology (NIST3.0) libraries provided with computer controlling the GC-MS system revealed that the essential oil of Long pepper contained different organic compounds that eluted at different retention times depending on the boiling point of the eluted component. The instruments data bank was also able to identify the presence of eugenol (98.979\%), trans-caryophyllene $(0.643 \%), 1,3,6$-Octatriene, 3, 7-dimethyl $(0.084 \%)$, Phenol, 2-methoxy-4-(2-propenyl), acetate (0.145\%), Preg-4-ene-3-one $(0.149 \%)$, with retention times of 34.39 , $35.313,36.598,39.59141 .933$ minutes respectively. 


\section{Bizuneh Adinew}

\section{Reported Biological Actions Eugenol}

Eugenol, an essential oil and the chief component of clove oil, is commonly used in the food industry, in aromatherapy and as a therapeutic agent in dentistry (Leal-Cardoso et al., 1994). Otherwise, despite its commercial use, eugenol may be found in large amounts among the essential oils of many plants most of them widely used in folk medicine (Leal-Cardoso et al., 1994). Although the action of eugenol is thought to be analgesic (Feng and Lipton, 1987; Thompson and Eling, 1989), authors reported that eugenol appears to have other
Sci. Technol. Arts Res. J., Jan-March 2014, 3(1): 31-38

actions (Sticht and Smith, 1971; Brodin and Roed, 1984). This compound reduces arterial blood pressure in dogs after intravenous injections, and increases blood flow after both intra-arterial and intravenous injections. Sticht and Smith, (1971), suggesting that the action of eugenol on the cardiovascular system might be on blood vessels. It was also reported that methyleugenol, an analogue of the phenolic compound eugenol, relaxes the isolated ileum and inhibits contractions induced by stimulation of voltage-dependent and receptor-operated channels (Lima et al., 2000).

Table 1: Phytocomponents identified in Long pepper essential oils.

\begin{tabular}{|c|c|c|c|c|c|}
\hline $\begin{array}{c}\text { Rt } \\
\text { (min.) }\end{array}$ & Compound & Structure & $\begin{array}{c}\text { Molecular } \\
\text { Formula }\end{array}$ & MW & Peak area \\
\hline 34.39 & $\begin{array}{c}\text { Eugenol } \\
\text { [Phenol, 2-methoxy-3-(2- } \\
\text { propenyl)- }\end{array}$ & & $\mathrm{C}_{10} \mathrm{H}_{12} \mathrm{O}_{2}$ & 164 & 26554529674 \\
\hline 35.313 & Trans-caryophyllene, & & $\mathrm{C}_{15} \mathrm{H}_{24}$ & 204 & 172593749 \\
\hline 36.598 & $\begin{array}{c}\text { 1,3,6-Octatriene, 3,7- } \\
\text { dimethyl, }\end{array}$ & & $\mathrm{C}_{10} \mathrm{H}_{16}$ & 136 & 22514527 \\
\hline 39.591 & $\begin{array}{l}\text { Phenol, 2-methoxy-4-(2- } \\
\text { propenyl)-, acetate }\end{array}$ & & $\mathrm{C}_{12} \mathrm{H}_{14} \mathrm{O}_{3}$ & 206 & 39014030 \\
\hline 41.933 & $\begin{array}{c}\text { Preg-4-ene-3-one } \\
\text { [1-(Cycloheptylamino)-3-(2 } \\
\text { naphthyloxy) propan-2-ol] }\end{array}$ & & $\mathrm{C}_{20} \mathrm{H}_{27} \mathrm{NO}_{2}$ & 313 & 39894375 \\
\hline
\end{tabular}

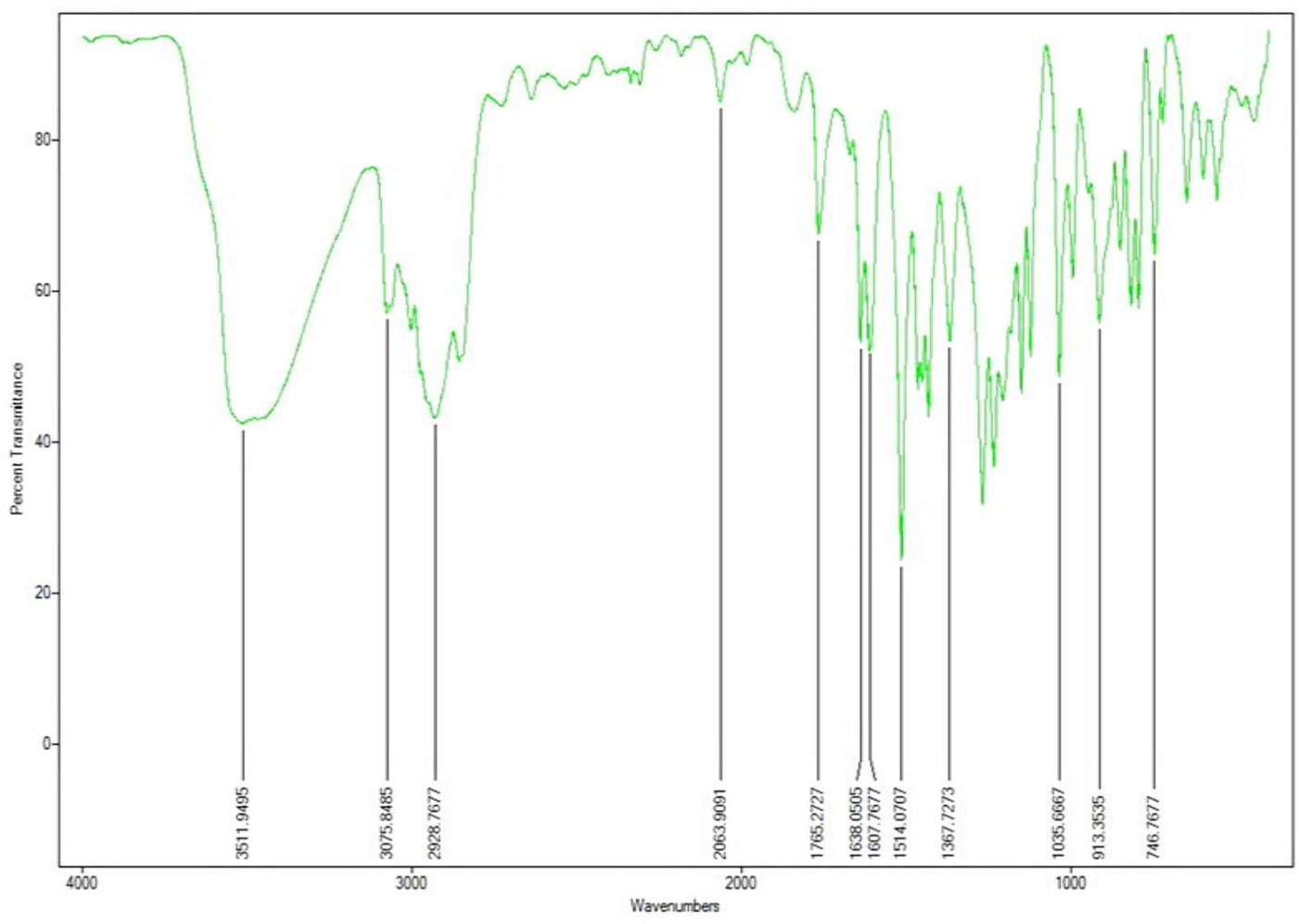

Figure1: FT-IR spectra of Long pepper essential oil. 


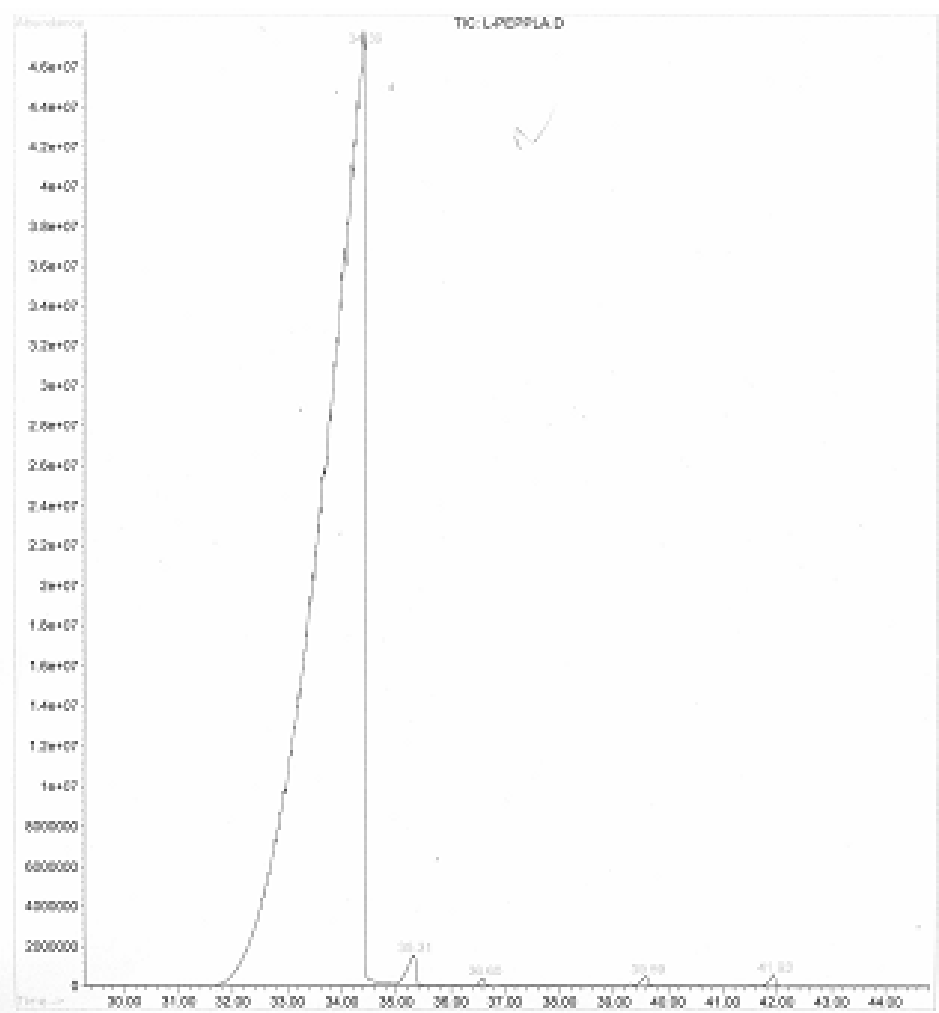

Figure 2: GC-MS profile of Long pepper essential oil

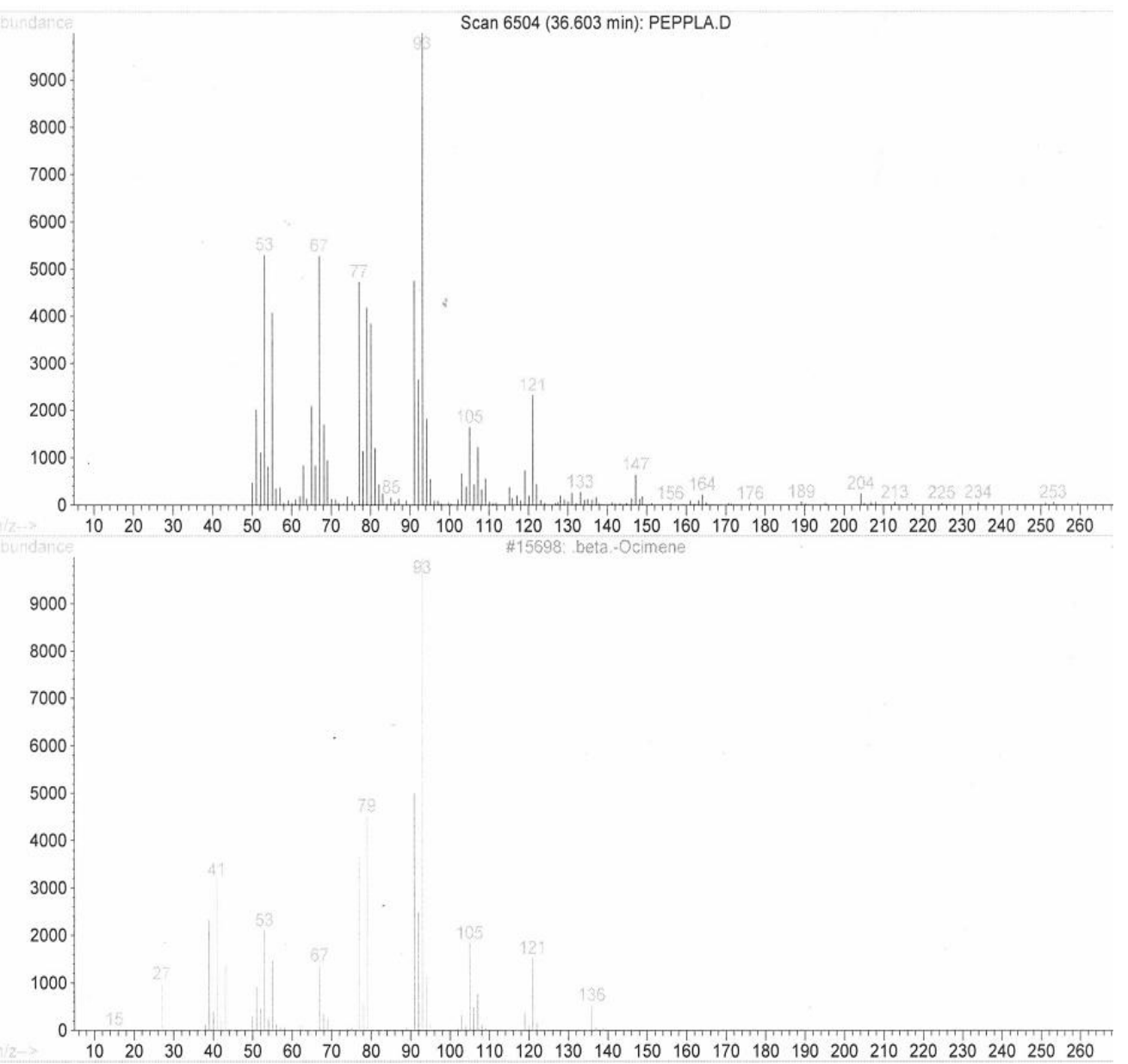

Figure 3: Mass profile of peak at Rt 35.313min; A GC- MS of peak eluted at Rt 35.313min; Trans-caryophyllene, 


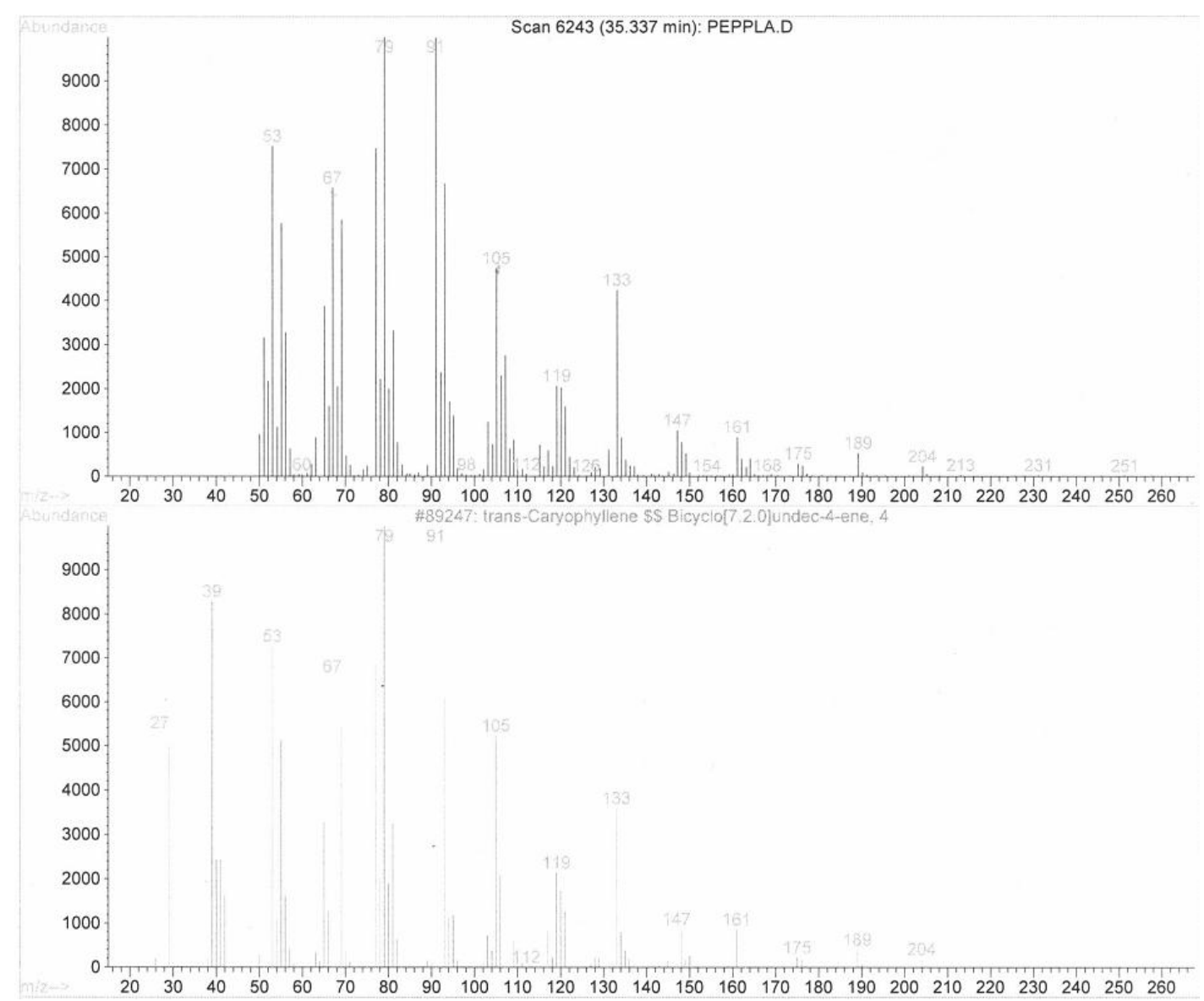

Figure 4: Mass profile of Peak at Rt 34.39min; A GC- MS of peak eluted at Rt 34.39min; Eugenol.

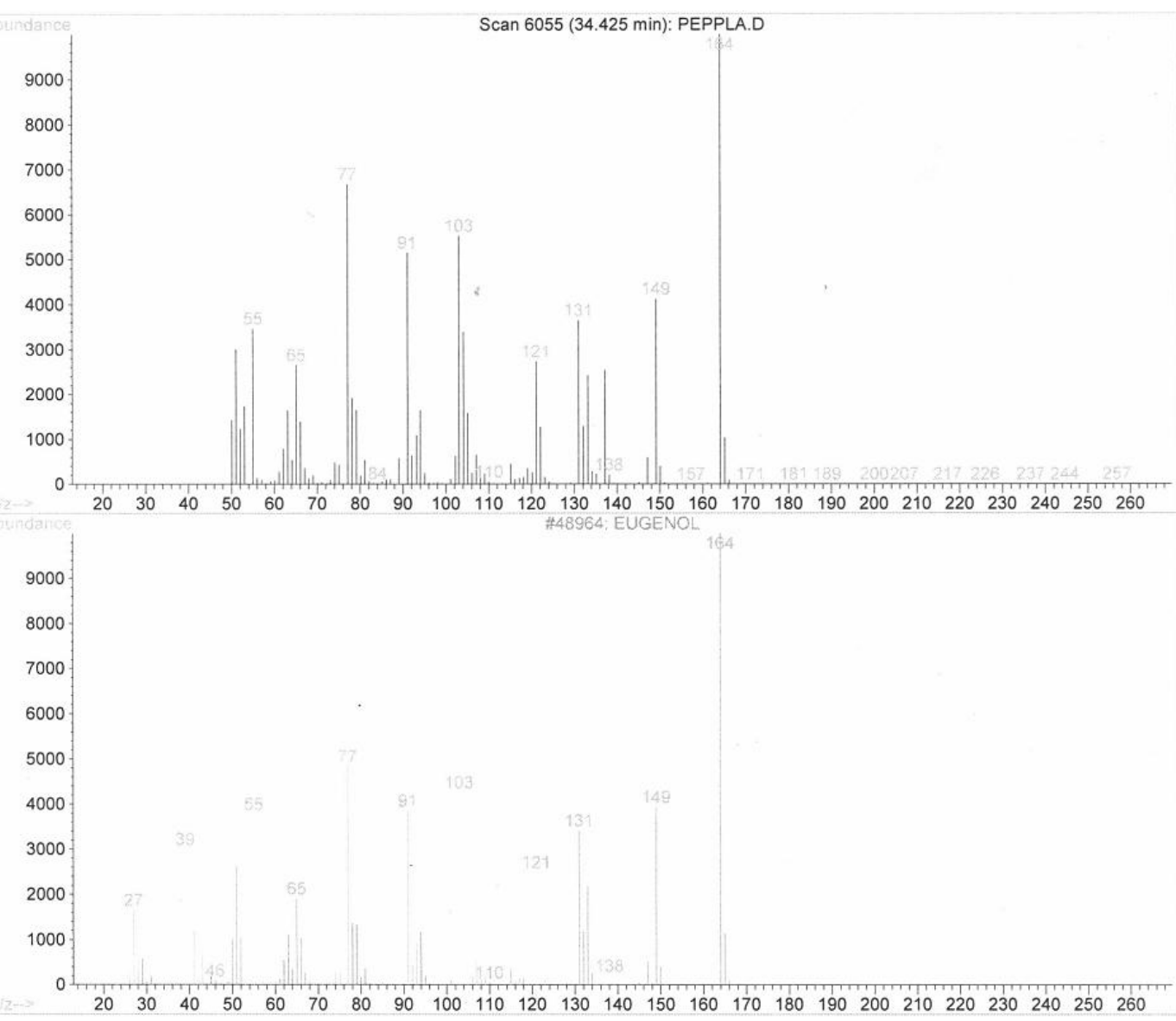

Figure 5: Mass profile of peak at Rt $36.598 \mathrm{~min}$; A GC- MS of peak eluted at Rt 36.598min; 1, 3, 6-Octatriene, 3, 7dimethyl. 


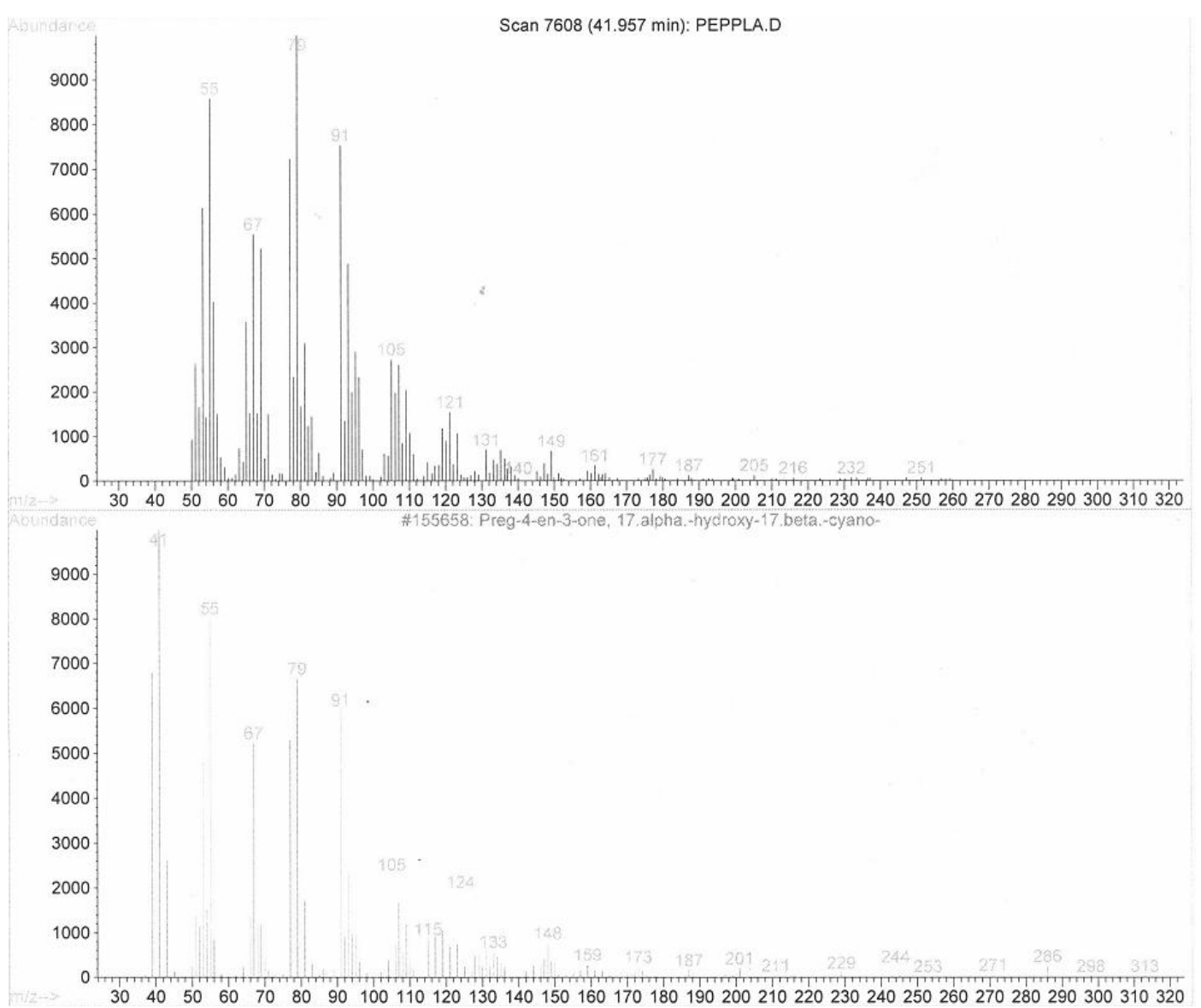

Figure 6: Mass profile of peak at Rt 39.591min; A GC- MS of peak eluted at Rt 39.591min; Phenol, 2-methoxy-4-(2propenyl)-, acetate.

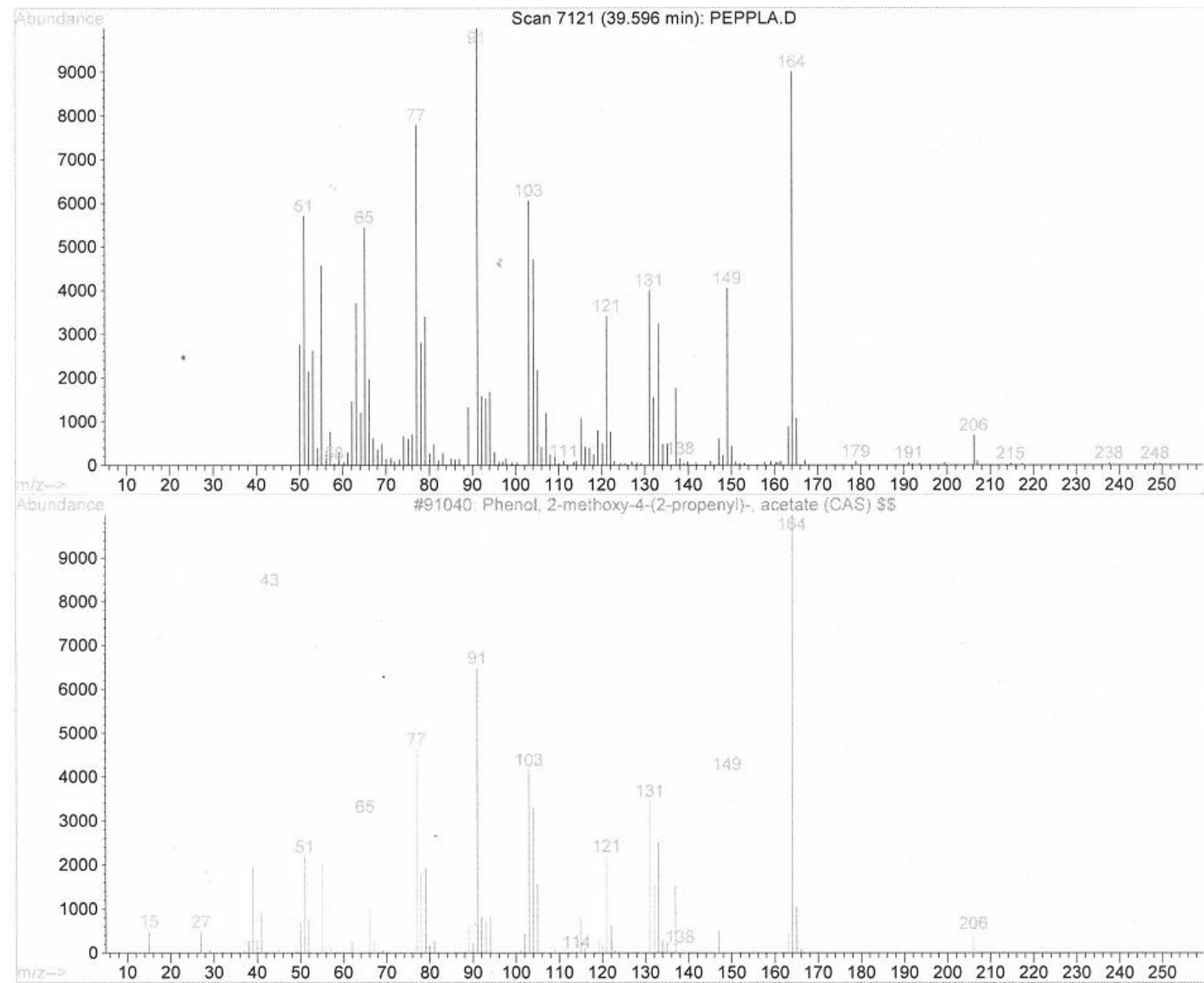

Figure 7: Mass profile of peak at Rt 41.933min; A GC- MS of peak eluted at Rt 41.933min; Preg-4-ene-3-one 


\section{Trans-Caryophyllene}

The terpenes, found in essential oils of different plants, are micro-constituents most commonly used as flavor additives in food, toiletries, and perfumes (Craveiro et al., 1981). Recent studies from different groups around the world have shown that terpenes and terpenoids exert a plethora of pharmacological effects (Leal-Cardoso and Fonteles, 1999). Trans-Caryophyllene is an important constituent of the essential oil of several species of plants. It is the major chemical constituent $(20.6 \%)$ of the essential oil of Pterodon polygalaeflorus (EOPp). EOPp blocks the electromechanical excitation-contraction coupling without affecting the pharmacomechanical coupling (Evangelista et al., 2007). The blocking effect caused by EOPp was suggested to result from inhibition of dihidropyridine sensitive $\mathrm{Ca}^{2+}$ channels, but there were no evidence to support that suggestion (Evangelista et al., 2007). Trans-Caryophyllene has been reported to possess many pharmacological effects. For example, it displays antimicrobial (Astani et al., 2011) and analgesic activity (Chavan et al., 2010). It activates the endocannabinoid system (Gertsch, 2008). TransCaryophyllene also has a well-documented antiinflammatory activity (Fernandes et al., 2007; Medeiros et al., 2007). Additionally, trans-caryophyllene is effective on intestinal smooth muscle, blocking the electromechanical and pharmacomechanical excitation-contraction coupling (Leonhardt et al., 2010). Those activities allow it to be considered as a potential anti-spasmodic agent in tracheal smooth muscle.

\section{CONCLUSIONS}

GC-MS analysis revealed that five different chemical components were identified in the essential oil of Long pepper, including eugenol (98.979\%), trans-caryophyllene $(0.643 \%), 1,3,6$-Octatriene, 3,7-dimethyl $(0.084 \%)$, Preg4-ene-3-one $(0.149 \%)$, and Phenol, 2-methoxy-4-(2propenyl)-, acetate (0.145\%). Eugenol comprises $98.979 \%$ of the essential oil extracted from Long pepper, and is the compound most responsible for the Long pepper s' aroma/ fragrant odor. The ingredients obtained from this study indicate that the oil can be fully utilized for the manufacture of perfumery products, antimicrobial and antiseptic agents.

\section{ACKNOWLEDGEMENT}

The author wishes to acknowledge Mizan-Tepi University for financial support and granting permission to utilize the facilities of the chemistry laboratory for carrying out the research work.

\section{REFERENCES}

Adam, R.P. (2001). Identification of essential oils components by gas chromatography/ quadrupole mass spectroscopy. Allured Publishing Corp, Carol Stream, IL.

Akgu I,A., Kivanc, M., Sert, S. (1991). Effect of carvacrol on growth and toxin production by Aspergillus flavus and Aspergillus parasiticus. Sciences des Aliments 11: 361370.

Akgul, A., Kivanc, M. (1988). Inhibitory effects of selected Turkish spices and oregano components on some foodborne fungi. International Journal of Food Microbiology 6: 263-268.

ASTA. (1968). Official analytical methods of the American Spice Trade Association. ASTA, Englewood Cliffs, 8-11.

Astani, A., Reichling, J., Schnitzler, P. (2011). Screening for Antiviral Activities of Isolated Compound from Essential
Oils. Evidence-Based Complementary and Alternative Medicine Article ID 253643.

Azzouz, M.A., Bullerman, L.B. (1982). Comparative antimycotic effects of selected herbs, spices, plant components and commercial antifungal agents. Journal of Food Protection 45(14): 1298-1301.

Bishop, C.D. (1995). Antiviral activity of the essential oil of Melaleuca alternifolia (Maiden and Betche) Cheel (tea tree) against tobacco mosaic virus. Journal of Essential Oil Research 7: 641-644.

Boyle, W. (1955). Spices and essential oils as preservatives. American Perfumer and Essential Oil Review 66: 25-28.

Brodin, P., Roed, A. (1984). Effects of eugenol on rat phrenic nerve and phrenic nerve diaphragm preparations. Archives of Oral Biology 29: 611-615.

Burbott, A.J., and W.D. Loomis, (1967). Effects of light and temperature on the monoterpenes of peppermint. Plant Physiology 42: 20-28.

Carson, C.F., Cookson, B.D., Farrelly, H.D., Riley, T.V. (1995). Susceptibility of methicillin resistant Staphylococcus aureus to essential oil of Melaleuca alternifolia. Journal of Antimicrobial Chemotherapy 35: 421-424.

Chavan, M.J., Wakte, P.S., Shinde, D.B. (2010). Analgesic and anti-inflammatory activity of Caryophyllene oxide from Annona squamosa L. bark. Phytomedicine, 17: 149-151.

Chialva, F., Gabri, G., Liddle, P.A.P. and Ulian, F. (1982). Qualitative evaluation of aromatic herbs by direct head space (GC) analysis. Applications of the method and comparison with the traditional analysis of essential oils, p. 183-195. In: Margaris, N. Koedam, A. and Vokou, D. (eds.). Aromatic plants-basic and applied aspect. Martinus Nijhoff, Netherlands

Craveiro, A.A., Fernandes, A.G., Andrade, C.H.S., Matos, F.J.A., Alencar, J.W., Machado, M.I.L. (1981). Óleos Essenciais de Plantas do Nordeste, UFC, Brazil.

Daferera, D.J., Ziogas, B.N., Polissiou, M.G. (2000). GC-MS analysis of essential oils from some Greek aromatic plants and their fungitoxicity on Penicillium digitatum. Journal of Agricultural and Food Chemistry 48: 2576-81.

Deans, S.G., Ritchie, G. (1987). Antibacterial properties of plant essential oils. International Journal of Food Microbiology 5: 165-180.

Denston, T.C. (1939). The volatile oils, A Textbook of Pharmacognosy. $3^{\text {rd }}$ Edn.

Dimandja J.M., Stanfill S., Grainger J., Patterson D. Jr. (2000). Application of comprehensive two-dimensional gas chro-matography (GC/GC) to the qualitative analysis of essential oils. Journal of High Resolution Chromatography 23: 208-214.

Donelian, A., Carlson, L.H.C., Lopes, T.J. and Machado, R.A.F. (2009). Comparison of extraction of patchouli (Pogostemon cablin) essential oil with supercritical CO2 and by steam distillation. The Journal of Supercritical Fluids 48: 15-20.

Evangelista, G.L., Coelho-de-Souza, A.N., Santos, C.F., Leal-Cardoso, J.H., Lopes, E.A., dos Santos, M.V., Lahlou, S., Magalhães, P.J. (2007). Essential oil of Pterodon polygalaeflorus inhibits electromechanical coupling on rat isolated trachea. Journal of Ethnopharmacology 109: 515-522.

Feng, J., Lipton, J.M. (1987). Eugenol: antipyretic activity in rabbits. Neuropharmacology 26: 1775-1778.

Fernandes, E.S., Passos, G.F., Medeiros, R., da Cunha, F.M., Ferreira, J., Campos, M.M., Pianowski, L.F., Calixto, J.B. (2007). Anti-inflammatory effects of compounds 


\section{Bizuneh Adinew}

alpha-humulene and (-)-trans-caryophyllene isolated from the essential oil of Cordia verbenacea. European Journal of Pharmacology 569: 228-236.

Gertsch, J. (2008). Anti-inflammatory cannabinoids in diet: Towards a better understanding of $C B$ (2) receptor action? Community Integrated Biology 1: 26-28.

Guenther, E. (1948). The Essential Oils. D. Van Nostrand, New York.

Hussain, A.I., Anwar, F., Sherazi, S.T.H. and Przybylski, R. (2008). Chemical composition. Antioxidant and antimicrobial activities of basil (Ocimum basilicum) essential oils depends on seasonal variations. Food Chemistry 108: 986-995.

Jayashree, T., Subramanyam, C. (1999). Antiaflatoxigenic activity of eugenol is due to inhibition of lipid peroxidation. Letters in Applied Microbiology 28: 179-183.

Juglal, S., Govinden, R., Odhav, B. (2002). Spice oils for the control of co-occurring mycotoxin-producing fungi. Journal of Food Protection 65(4): 683-687.

Karpouhtsis, I., Pardali, E., Feggou, E., Kokkini, S., Scouras, Z.G., Mavragani Tsipidou, P. (1998). Insecticidal and genotoxic activities of oregano essential oils. Journal of Agricultural and Food Chemistry 46: 1111-1115.

Khajeh, M.Y., Yamini, F. Sefidkon and Bahramifar, N. (2004). Comparison of essential oil composition of Carum copticum obtained by supercritical carbon dioxide extraction and hydrodistillation methods. Food Chemistry 86: $587-591$.

Konstantopoulou, I., Vassilopoulou, L., Mavragani-Tsipidou, P., Scouras, Z.G. (1992). Insecticidal effects of essential oils. A study of the effects of essential oils extracted from eleven Greek aromatic plants on Drosophila auraria. Experientia 48(6): 616-619.

Kulisic, T., Radonic, A., Katalinic, V. and Milos, M. (2004). Use of different methods for the testing activity of oregano essential oil. Food Chemistry 85: 633-640.

Leal-Cardoso, J.H.; Fonteles, M.C. (1999). Pharmacological effects of essential oils of plants of the northeast of Brazil. The Anais da Academia Brasileira de Ciências 71: 207213.

Leal-Cardoso, J.H., Coelho de Souza, A.N., Souza, I.T., Figueiredo, I.M. (1994). Effects of eugenol on excitationcontraction coupling in skeletal muscle. Archives internationales de pharmacodynamie et de thérapie 327 113-124.

Leonhardt, V., Leal-Cardoso, J.H., Lahlou, S., Albuquerque, A.A., Porto, R.S., Celedônio, N.R., Oliveira, A.C., Pereira, R.F., Silva, L.P. and Garcia-Teófilo, T.M. (2010). Antispasmodic effects of essential oil of Pterodon polygalaeflorus and its main constituent betacaryophyllene on rat isolated ileum. Fundam. Clin. Pharm., 24, 749-758.

Lima, C.C., Criddle, D.N., Coelho-de-Souza, N.A., Monte, F.J., Jaffar, M., Leal-Cardoso, J.H. (2000). Relaxant and antispasmodic actions of methyleugenol on guinea-pig isolated ileum. Planta Medica 66: 408-411.

Mahmoud, S.S., Croteau, R.B. (2002). Strategies for transgenic manipulation of monoterpene biosynthesis in plants. Trends in Plant Science 7(8): 366-373.

Mari, M., Bertolini, P., Pratella, G.C. (2003). Nonconventional methods for the control of post-harvest pear diseases. Journal of Applied Microbiology 94: 761-766.

Masango, P. (2004). Cleaner production of essential oil by steam distillation. Journal of Cleaner Production 13: 833839.
Sci. Technol. Arts Res. J., Jan-March 2014, 3(1): 31-38

Massda, Y., (1976). Analysis of essential oils by Gas Chromatography and Mass Spectrometry. Halsted/Wiley, New York.

Medeiros, R., Passos, G.F., Vitor, C.E., Koepp, J., Mazzuco, T.L., Pianowski, L.F., Campos, M.M., Calixto, J.B. (2007). Effect of two active compounds obtained from the essential oil of Cordia verbenacea on the acute inflammatory responses elicited by LPS in the rat paw. British Journal of Pharmacology 151: 618-627.

Mourey, A., Canillac, N. (2002). Anti-Listeria monocytogenes activity of essential oils components of conifers. Food Control 13: 289-292.

Nychas, G.J.E. (1995). Natural antimicrobials from plants. In: Gould, G.W. (Ed.), New Methods of Food Preservation. Blackie Academic and Professional, London, pp. 58-89.

Pandey, R., Kalra, A., Tandon, S., Mehrotra, N., Singh, H.N., Kumar, S. (2000). Essential oil compounds as potent source of nematicidal compounds. Journal of Phytopathology 148(7-8): 501-502

Pessoa, L.M., Morais, S.M., Bevilaqua, C.M.L., Luciano, J.H.S. (2002). Anthelmintic activity of essential oil of Ocimum gratissimum L. \& eugenol against Haemonchus contortus. Veterinary Parasitology 109(1-2): 59-63.

Reverchon, E. (1997). Supercritical fluid extraction and fractionation of essential oils and related products. Journal of Supercritical Fluids 10: 1-37.

Shelef, L.A. (1983). Antimicrobial effects of spices. Journal of Food Safety 6: 29-44

Sheille R., Mondello L., Marriott P., Dugo G. (2002). Characterisation of lavender essen-tial oils by using gas chromatography-mass spectrometry with correlation of linear reten-tion indices and comparison with comprehensive two-dimensional gas chromatography. Journal of Chromatography A 970: 225-234.

Silva, M.G.V., Matos, F.J.A., Lopes, P.R.O., Silva, F.O. and Holanda, M.T. (2004). Composition of essential oils from three Ocimum species obtained by steam and microwave distillation and supercritical $\mathrm{CO}_{2}$ extraction. ARKIVOC. 6: 66-71.

Sokovic, M. and Van Griensven, L.J.L.D. (2006). Antimicrobial activity of essential oils and their components against the three major pathogens of the cultivated button mushroom, Agaricus bisporus. European Journal Plant Pathology 116: 211-224.

Sticht, F., Smith, R.M. (1971). Eugenol: some pharmacologic observations. Journal of Dental Research 50: 1531-1535.

Thompson, D., Eling, T. (1989). Mechanism of inhibition of prostaglandin $\mathrm{H}$ synthase by eugenol and other phenolic peroxidase substrates. Molecular Pharmacology 36: 809817.

Tuley de Silva, K. (Ed.) (1996). A Manual on the Essential Oil Industry. United Nations Industrial Development Organization, Vienna.

Ultee, A., Smid, E.J. (2001). Influence of carvacrol on growth and toxin production by Bacillus cereus. International Journal of Food Microbiology 64: 373-378.

Van de Braak, S.A.A.J., Leijten, G.C.J.J. (1999). Essential Oils and Oleoresins: A Survey in the Netherlands and other Major Markets in the European Union. CBI, Centre for the Promotion of Imports from Developing Countries, Rotterdam, Pp. 116.

Whish, J.P.M. and Williams, R.R. (1996). Effects of post harvest drying on the yield of tea tree oil (Melaleuca alternifolia). Journal of Essential Oil Research 8: 47-51. 